\title{
THE EFFECT OF CEREAL TYPE AND NON-STARCH POLYSACCHARIDE (NSP) DEGRADING ENZYMES ON BROILER PERFORMANCE AND NUTRIENT UTILIZATION
}

\author{
T.M. Younis ${ }^{1}$; F.A. Mohammed ${ }^{1}$; F.M. Attia ${ }^{1}$; M.A.M. Sayed ${ }^{2}$ and A.E. Shams-Eldein ${ }^{2}$ \\ ${ }^{1}$ Department of Animal Production, Faculty of Agriculture, Al-Azhar University, Nasr City, Cairo, \\ Egypt.
}

${ }^{2}$ Poultry Nutrition Research Dept., Animal Production Research Inst., Dokki, Egypt.

\section{SUMMARY}

$\mathrm{T}$ he aim of this work is to study the effects of cereal type (corn or wheat-based diets), and multicarbohydrase enzyme supplementation to broiler diets containing recommended, intermediate ($100)$ or low (-150) Kcal/kg ME energy levels and their interactions on broiler performance, protein and energy efficiency ratios, nutrient digestibility, carcass traits and some blood measurements.

A total of 480, seven day-old unsexed Cobb500 broiler chicks of $160 \mathrm{~g}$ average body weight were randomly divided into eight experimental treatments and three replicates per treatment group. The experiment consisted of 3 growing phases \{starter $(7-14 d)$, grower $(15-28 d)$ and finisher $(29-42 d)$ \}. Diets were formulated to contain 21, 19 and $18 \%$ protein levels and 2988, 3083 and $3176 \mathrm{kcal} / \mathrm{kg} \mathrm{ME}$ during the starter, grower and finisher phases, respectively. During each growing phase, each group was fed on one of the following experimental diets: corn-soybean based diet without supplementation(C), wheat-soybean based diet without supplementation (W), corn-soybean based diet supplemented with enzymes cocktail at level of $50 \mathrm{~g} / 100 \mathrm{~kg}$ diet $(\mathrm{C}+)$, wheat-soybean based diet supplemented with enzymes cocktail at level of $50 \mathrm{~g} / 100$ $\mathrm{kg}$ diet $(\mathrm{W}+)$, low energy $(100 \mathrm{kcal})$ corn-soybean based diet supplemented with enzymes cocktail at level of $50 \mathrm{~g} / 100 \mathrm{~kg}$ diet (LC100+), low energy (-100 kcal) wheat-soybean based diet supplemented with enzymes cocktail at level of $50 \mathrm{~g} / 100 \mathrm{~kg}$ diet (LW100+), low energy $(150 \mathrm{kcal})$ corn - soybean based diet supplemented with enzymes cocktail at level of $50 \mathrm{~g} / 100 \mathrm{~kg}$ diet (LC150+) or low energy (-150 kcal) wheatsoybean based diet supplemented with enzymes cocktail at level of $50 \mathrm{~g} / 100 \mathrm{~kg}$ diet (LW150+). The carbohydrase enzymes cocktail supplement supplied per $1 \mathrm{~g}, 3000 \mathrm{U} \alpha$-galactosidase, $5000 \mathrm{U} \beta$ - mannanase $2500 \mathrm{U}$ xylanase, $1500 \mathrm{U} \beta$ - glucanase and $1000 \mathrm{U}$ cellulose.

The obtained results could be summarized as follows: birds fed the corn-based diets had overall superior weight gain, feed consumption, feed conversion ratio, nutrient digestibility and protein and energy conversion ratio compared with those fed the wheat-based diets. Enzyme cocktail supplementation to corn or wheat based diets improved all tested parameter cited above. No significant differences were found between the low ME enzymes supplemented diets (L100+ and L150+) and their respective control groups for body weight gain during the overall period. Enzymes supplementation to low energy diets compensate for lowering energy level by increasing feed consumption.

Birds fed corn based diets or enzyme supplemented diets, irrespective of cereal type, had significantly high blood plasma glucose level. On the other hand, neither cereal type nor enzyme supplementation had a significant effect on blood plasma total proteins and total lipids. Chicks fed corn based diet improved EPEI (European production efficiency index) by $18.21 \%$ compared to those fed wheat based diet and enzyme supplementation to corn or wheat based diets improved significantly EPEI and the improvement was more pronounced for wheat based diet compared to corn based diet (13.03 vs. 5.03). No significant differences in EPEI were detected when enzyme cocktail was added to low AME diets based on corn or wheat.

Keywords: Broiler, cereal based diets, enzyme supplementation, performance and nutrient utilization.

\section{INTRODUCTION}

The long-term sustainability of commercial broiler production is dependant on both economic and environmental constraints. Since the feed is one of the major costs associated with broiler production and the initial source of pollutants, there are considerable pressures to reduce feed costs and minimize the polluting effects of the feed.

Consistent increase in the price of feed ingredients has been major constraint in most of the developing countries. As a consequence cheaper and nonconventional feed ingredients have to be used which contain higher percentage of non-starch polysaccharides (NSP's) along with starch. For example, Despite, maize being the most commonly used cereal grain in poultry diet formulation world-wide 
because of its high available energy content and low soluble non-starch polysaccharides, which are an anti-nutrient factor (Iji et al., 2003), wheat is an important energy feedstuff that is widely used throughout the European Union due to inland cultivation and low price, and is also the cereal grain of choice for whole grain feeding.

However, wheat contains arabinoxylans at concentrations of 50 to $80 \mathrm{~g} / \mathrm{kg}$ DM that act as NSP and effectively depress AME (Annison et al., 1987). The average total content of NSP's was analyzed to be $104.8 \mathrm{~g} / \mathrm{kg} \mathrm{DM}$, whereas the evaluation of wheat AME values ranging from 9.2 to14.9 MJ/kg DM, and AME was negatively correlated with all fractions of NSP's (Choct et al., 1999).

The term NSP's refers to indigestible polysaccharides of different physiochemical properties that have various negative effects on bird digestion and ultimately, production. The NSP's are not well digested by poultry (Annison, 1993), and a part of these NSP's is water-soluble which is notorious for forming a gel like viscous consistency in the intestinal tract (Ward, 1995) thus reducing gut performance .Also, predominantly water soluble and viscous arabinoxylans are assumed to increase the water intake by the birds, which lead to unmanageable litter problems caused by wet and sticky droppings. This deteriorates the hygienic conditions and carcass quality (Dunn, 1996). Non-starch polysaccharides (NSP) in cereals and in vegetable proteins, may also play a role as an energy storage material.

With advances in biotechnology and fermentation processes, cost of production of feed enzymes has dramatically reduced, and the use of feed enzymes in poultry diets has become popular. Research work has suggested that the negative effects of NSP's can be overcome by dietary modifications including supplementation of diets with suitable exogenous enzyme preparations (Creswell, 1994).

Therefore, use of commercially available exogenous enzymes preparations in poultry nutrition to target specific substrates in the feeds and ameliorate their antinutritive effect and to reduced pollution problems arising from an excessive output of excreta containing large amounts of organic matter, as well as to increase the choice and content of ingredients which are acceptable for inclusion in diets has received increased attention in the last decade (Acamovic, 2001). However, the selection of a correct type and amount of an enzyme and its method of mixing with diet would be essential to achieve the objectives of a successful broiler production system (Anjum and chaudhry, 2010).

Benefits of using feed enzymes to poultry diets include ; reduction in digesta viscosity, enhanced digestion and absorption of nutrient, improved apparent metabolizable energy (AME) value of the diet, increased feed intake, weight gain and feed - gain ratio, reduced beak imprecation and vent plugging, decreased size of gastrointestinal tract, altered population of microorganisms in gastrointestinal tract, reduced water content of excreta (Annison, 1993; Bedford and Schulze, 1998; Simon, 1998; DudleyCash, 2001; Sheppy, 2001).

One of the main reasons for supplementing wheat and barley - based poultry diets with enzymes is to increase the available energy content of the diet. Increased availability of carbohydrates for energy utilization is associated with increased energy digestibility (Van der Kils et al., 1995). The improvement in wheat AME resulting from enzyme supplementation are variable because of the variability in the NSP content and structure of wheat (Pirgozliev et al., 2003 and Smeets et al., 2014). Classen et al., (1995), Schutte et al. (1995) and Van der kils et al. (1995) reported improvements of 5-16, 3.1-4.5, and $4.5-$ $12.4 \%$ respectively.

Also, adding adequate activity levels of $\alpha$-Amylase, $\beta$-glucanase and xylanase to broiler starter and grower corn - soybean diets with a $3 \%$ reduction in dietary ME allowed full restoration of growth performance of broilers comparable to those fed the adequate energy (Yu and Chang, 2004).

Exact biochemical function of enzyme mixtures within the lumen remains unclear. However, one thing is certain; exogenous enzyme supplementation does not improve growth through the complete hydrolysis of polysaccharide and subsequent monosaccharide absorption. Instead, de-polymerization of the polysaccharide into smaller polymers aids in digestibility by decreasing overall digesta viscosity (Choct, 2001).

Therefore, the aim of this work is to study the effect s of cereal type (corn or wheat -based), and multi-carbohydrase enzyme supplementation), to broiler diets had recommended - intermediate (100 $\mathrm{Kcal} / \mathrm{kg}$ lower) - and low (150 Kcal/kg lower) ME energy levels and their interactions on broiler performance, protein and energy efficiency ratios, nutrient digestibility, carcass traits and some blood measurements.

\section{MATERIAL AND METHODS}

A total of 480 seven day-old unsexed Cobb500 broiler chicks of 160 gm average body weight were randomly divided into eight experimental treatments and three replicates per treatment group. Birds were 
vaccinated against avian influenza, Newcastle and gumboro diseases. All the recommended practices for broiler rearing were followed throughout the experimental period. Mash diets and fresh water was offered ab libitum. Experimental periods lasted for 42 days at poultry experimental station, faculty of agriculture, Al-Azhar University, Cairo, Egypt.

\section{Experimental design and diets:}

The experiment consisted of 3 growing phases (7-14d, starter; 15-28 d, grower and 29-42d, finisher). Antibiotic and Coccidiostate-free diets were formulated to contain 21, 19 and $18 \%$ protein levels and 2988, 3083 and $3176 \mathrm{kcal} / \mathrm{kg}$ ME during the starter, grower and finisher phases, respectively. During each growing phase, each group was fed on one of the following experimental diets:

1. Corn - soybean based diet without supplementation (C).

2. Wheat - soybean based diet without supplementation (W).

3. Corn-soybean based diet supplemented with enzymes cocktail at level of $50 \mathrm{gm} / 100 \mathrm{~kg} \operatorname{diet}(\mathrm{C}+)$.

4. Wheat-soybean diet supplemented with enzymes cocktail at level of $50 \mathrm{gm} / 100 \mathrm{~kg}$ diet (W+).

5. Low energy $(100 \mathrm{kcal})$ corn - soybean based diet supplemented with enzymes cocktail at level of 50 $\mathrm{gm} / 100 \mathrm{~kg} \operatorname{diet}(\mathrm{LC} 100+)$.

6. Low energy (100 kcal) wheat - soybean based diet supplemented with enzymes cocktail at level of $50 \mathrm{gm} / 100 \mathrm{~kg} \operatorname{diet}(\mathrm{LW} 100+)$.

7. Low energy $(150 \mathrm{kcal})$ corn - soybean based diet supplemented with enzymes cocktail at level of 50 $\mathrm{gm} / 100 \mathrm{~kg} \operatorname{diet}(\mathrm{LC} 150+)$.

8. Low energy $(150 \mathrm{kcal})$ wheat - soybean based diet supplemented with enzymes cocktail at level of $50 \mathrm{gm} / 100 \mathrm{~kg} \operatorname{diet}(\mathrm{LW} 150+)$.

The carbohydrase enzymes cocktail supplement supplied per $1 \mathrm{gm}, 3000 \mathrm{U} \alpha$-galactosidase, $5000 \mathrm{U}$ $\beta$ - mannanase $2500 \mathrm{U}$ xylanase, $1500 \mathrm{U} \beta$ - glucanase and $1000 \mathrm{U}$ cellulase.

\section{Productive performance traits:}

Weekly records on live body weights of chicks and feed intake were maintained on replicate group basis. Thus, body weight gain and feed conversion were calculated weekly. Mortality was monitored and recorded daily.

\section{Protein and energy efficiency ratios:}

Protein conversion ratio (PCR) and energy conversion ratio (ECR) were calculated for each growing phase and for whole period as following formula:

PCR $(\mathrm{g}$ protein/g gain $)=$ protein intake $(\mathrm{g}) /$ body weight gain $(\mathrm{g})$

$\mathrm{ECR}(\mathrm{Kcal} / \mathrm{g}$ gain $)=$ gross energy intake $(\mathrm{Kcal}) /$ body weight gain $(\mathrm{g})$

\section{Digestibility trails:}

During the 6th week of age, digestibility trails were conducted for evaluating nutrient digestibility of the experimental diets. The proximal analysis of the experimental diets and dried excreta were determined according to the official of analysis (AOAC, 1990). In order to estimate protein digestibility fractions of fecal and urinary nitrogen in the excreta were chemically separated according to the method of Jacobsen et al. (1960).Digestibility coefficients percentage were calculated for organic matter (OM), crude protein (CP), ether extract (EX) crude fiber (CF) and nitrogen free extract (NFE).

\section{Determination of metabolizable energy (AME):}

Gross energy determination was done on the experimental diets and excreta in the digestibility trial by using an IKA - Calorimeter C4000 adiabatic bomb calorimeter.

The apparent metabolizable energy values (AME) were calculated as follows:

$\mathrm{AME}(\mathrm{K} \mathrm{Cal} / \mathrm{gm})=\mathrm{EI}-\mathrm{ExE} / \mathrm{FI}$

Corrected apparent metabolizable energy values to zero nitrogen balance (AMEn) were calculated by using the formula of sibbald et al., (1960).

$\mathrm{AMEn}=\mathrm{EI}-[\mathrm{ExE}+(\mathrm{NR} * 8.22)] / \mathrm{FI}$

Where: $\mathrm{EI}=$ Energy Intake.

$\mathrm{ExE}=$ Excreta energy.

$\mathrm{FI}=$ Feed intake.

$\mathrm{NR}=$ Nitrogen retained $=\mathrm{NI}-\mathrm{ExN}$

$\mathrm{NI}=$ Nitrogen intake

ExN= Nitrogen excreted

8.22: The energy in Kcal / g nitrogen retained by the bird (Hill and Anderson, 1958). 


\section{Carcass traits:}

At the end of the experiment (42days of age) six birds were selected from each treatment (group) on the basis of average body weight and slaughtered by slitting the jugular vein. The birds were then immediately scalded, feather plucked and eviscerated. Records on individual weights of eviscerated carcass and edible organs (heart, liver, and skinned empty gizzard). Total edible parts were calculated as eviscerated carcass plus giblets. All measurements were expressed in terms of percentage of live weight at slaughter.

\section{Blood parameters:}

During the slaughter process blood samples were collected from the jugular vein in heparinized tubes. Blood samples were centrifuged at 3000 r.p.m for 10 minutes and plasma was stored at $\left(-20{ }^{\circ} \mathrm{CD}\right)$. Individual plasma sample were analyzed using commercial kits for Total protein, albumin, aspartate amino transferases, alanine amino transferases, total lipids and total cholesterol according to methods of Doumas et al. (1981), Doumas and Bigg (1972), Reitman and rankel,(1957), Chabrol and Charonnat, (1937) and Flegg (1973), respectively.

\section{Production efficiency:}

Evaluating production efficiency was carried out using the European production efficiency index (EPEI) according to Hubbard broiler management guide (1999).

The equation that was used is as follow:

$\mathrm{EPEI}=((\mathrm{BW}(\mathrm{kg}) * \mathrm{LA}) /(\mathrm{PP} * \mathrm{FCR})) * 100$

Where: BW = Body weight $(\mathrm{kg}), \mathrm{LA}=$ Livability $(100-\%$ mortality $), \mathrm{PP}=$ production period (days), $\mathrm{FCR}=$ Feed conversion ( $\mathrm{kg}$ Feed $/ \mathrm{kg}$ gain in live body weight).

\section{Statistical analysis:}

Data were analyzed by using one way ANOVA of the GLM procedure of SAS (SAS Institute, 1990). Duncan's multiple range tests was used to determine differences among means when treatment effect were significant Duncan (1955).

\section{RESULTS AND DISCUSSION}

The effects of cereal type and enzyme supplementation on the performance of broilers are presented in table (4). Chicks fed corn based diet consumed slightly insignificant more feed than the wheat based fed chicks (370 vs. 364g) in the starter phase. In the growing, finishing and over the entire trail, birds consumed significantly more corn based diet than wheat based diets (1621 vs 1603, 1995 vs. 1967 and 3986 vs. 3934 g, respectively). During all trail periods enzyme supplementation resulted in an increase in feed consumption regardless of cereal type (corn or wheat), except for wheat based diet during starter period where the differences was insignificant. However, the effect was more pronounced for birds fed wheat based diet compared to corn based diets. The improvement in feed intake was 1.12, 1.42, and 1.32 $\%$ during grower, finisher and over the entire trail, respectively.

Body weight gain $(\mathrm{BWG})$ was increased significantly $(\mathrm{P}<0.05)$ when the corn- based diet was fed during the entire experiment compared with the bird fed wheat- based diets. The percentage improvements were 7.57, 3.36, 21.8 and 11.48 for starter, grower, finisher and total period, respectively. Body weight gain was significantly $(\mathrm{P}<0.05)$ increased by enzyme supplementation. The total improvement in body weight gain was $3.21 \%$ and $7.73 \%$ for corn and wheat-base diets compared to the un-supplemented control diets, respectively.

Feed per gain ratio (FCR) was affected by cereal type (corn vs wheat), feeding corn-based diet had significant and positive effect on feed per gain compared to its counterpart with wheat-based diet. The corresponding improvement with corn feeding were estimated to be 6.12,16.6, and $8.91 \%$ during starter, finisher and overall period, respectively relative to results reported for wheat based diet. Enzyme supplementation ameliorate feed conversion ratio by $2.72 \%$ and $5.94 \%$ for chicks fed corn-based and wheat based diets, respectively during the total experimentation.

Results in table (5) show the effect of enzyme supplementation to low energy diets on broiler performance. There were no significant differences between the low AME enzyme supplemented diets(L100+ and L150+) and their respective control group (Corn and wheat) for body weight gain during grower, finisher and over all period. It's obvious that both feed intake and feed conversion ratio were significantly $(\mathrm{P}<0.05)$ affected by treatments for each growth interval. Feed intake, increased by decreasing AME content of broiler diets supplemented by enzyme cocktail regardless of cereal type. On 
the other hand, decreasing AME content of broiler ration supplemented by enzymes tend to increase slightly feed per gain ratio. The effect was more pronounced for group (LC150+).

The results indicating that, Birds fed low AME diets compensate for the lack of energy by increasing feed intake as might be expected and in fact had a significantly higher Feed Intake compared to birds fed the adequate energy diets.

Results in tables $(6,7)$ revealed that cereal type ( corn or wheat ) had insignificant effect on digestibility coefficient of crude protein (CP), Ether extract (EE) and crude fibre $\mathrm{CF}$ and also on feeding value in terms of apparent metabolizabel energy (AME). However, inclusion of corn instead of wheat in broiler diets increased slightly the values of digestibility coefficient of $\mathrm{CP}, \mathrm{EE}$ and $\mathrm{CF}$ and also AME.

On the other hand enzyme supplementation to broiler diets improved significantly the digestibility coefficient of (EE) and the effect was mor pronounced when wheat is used as main source of energy in broiler diets compared to corn. In addition, enzyme supplementation increased numerically but insignificant the digestibility coefficient of (CP) and (CF) and the nutrition value in term of (AME).

The increase in improvement for digestion coefficient values of all tested parameters when wheat is used may be due to that corn is not regarded as viscous feedstuffs even though it do contain appreciable amount of NSP's (Bach Kundsen, 1996). The increase in (EE) digestibility irrespective of cereal type by enzyme supplementation may be due to that the absorption of large molecules is affected to greater extent by increased viscosity than smaller molecules (Choct and Annison, 1992 and classen, 1996). In this regard the response in lipid digestion with enzyme supplementation is greater compared to protein digestion (Choct Annison, 1992).

Results in table $(8,9)$ show the effect of cereal type and enzyme supplementation on protein and energy conversion ratios. Results indicated that formulation of broiler diets based on corn improved significantly protein and energy conversion ratio by $8.3 \%$ and $7.3 \%$ respectively, compared to wheat. Also, enzyme supplementation tends to improve protein and energy conversion ratio irrespective of cereal type (corn or wheat). However, the improvement was more pronounced in case of wheat based diet (5.4 and $6.19 \%$ for protein and energy, respectively) compared to corn based diet ( 2.8 and $2.0 \%)$ for protein and energy, respectively.

Regarding the effect of enzyme supplementation to low energy diets on protein and energy conversion ratio, data in tables $(10,11)$ revealed that enzyme supplementation to low energy corn or wheat based diets (LC100+ and LC150+ or LW100+ and LW150+ ) had no significant effect on energy conversion ratio within each cereal type. The same trend was observed for protein conversion ratio. The results indicated that enzyme supplementation compensate for the decrease in energy level by 100 or $150 \mathrm{kcal} /$ $\mathrm{kg}$ diet regardless of cereal type.

The data on carcass traits at 6 week old broiler chicks as affected by cereal type and enzyme supplementation are shown in tables $(12,13)$. Cereal type had no significant effect all carcass traits studied. However, enzyme supplementation, significantly, have positive effect $(\mathrm{P}<0.05)$ on relative weight of gizzard regardless of cereal type. In general, enzyme supplementation increases numerically but insignificant relative weights of different segments of gastro intestinal tract (liver, heart and abdominal fat).

Results in tables $(14,15)$ summarize the effects of cereal type and enzyme supplementation on blood serum glucose, total proteins and total lipids levels at 42 day of age. Data revealed that birds fed corn based diet had significantly higher blood glucose level compared to those fed wheat based diet (289 vs $210 \mathrm{mg} / \mathrm{dl}$ ). Enzyme supplementation ameliorates blood glucose level by $9.4 \%$ and $19.2 \%$ for chicks fed corn-based and wheat based diets, respectively during the total experimentation. On the other hand, cereal neither type nor enzyme supplementation had a significant effect on blood plasma total proteins and total lipids.

The effects of cereal type and enzyme supplementation on the European Production Efficiency Index (EPEI) of broilers are presented in table $(16,17)$. Chicks fed corn based diet improved EPEI by $18.21 \%$ compared to those fed wheat based diet. Enzyme supplementation to corn or wheat based diets improved significantly EPEI and the improvement was more pronounced for wheat based diet compared to corn based diet (13.03 vs $5.03 \%)$. On the other hand, no significant differences in EPEI were detected when enzyme cocktail was added to low AME diets based on corn or wheat, However, the improvement was more pronounced for birds fed enzyme supplemented low AME corn based diets (Table 17).

The results of the current study showed that birds fed the corn-based diets had overall superior WG, FI and FCR, nutrient digestibility and protein and energy efficiency ratio compared with those fed the wheat-based diets. In general, wheat has lower nutritional value than corn because it contains high amounts of water-soluble and viscous NSP's (Leeson \& Summers, 2005).It is generally assumed that NSP's exhibit anti-nutritional effects through different ways. Firstly by increasing digesta viscosity through the release of soluble NSP's leached from cell walls (Chesson, 2001) which may result in reduced rates of diffusion of nutrients and/or reduced feed passage time (and thus ingestion)(Classen, 
1996). Secondly it is thought that soluble NSP's increases the size and solidity of the unstirred layer at the mucosal surface of the digestive tract, resulting in limited contact between the digestive enzymes and the substrates (Chesson, 2001). Thirdly, by encapsulating the starch, fat and protein in the feed (Cowan et al., 1996) forming a physical barrier between the digestive enzymes and the substrates to be digested. Fourthly, by altering the microbial profile of the digestive tract (Choct et al., 1999) and promoting bacterial proliferation to the detriment of digestive efficiency and bird health (Choct et al., 1996). Lastly, by altering intestinal morphology. Mathlouthi et al. (2002) found that the addition of xylanase andglucanase to rye based diets increased $(\mathrm{P}<0.05)$ villi size and the villus height to crypt depth ratio, as well as the concentration of conjugated bile acids $(\mathrm{P}<0.05)$ in the small intestinal contents leading to increased nutrient absorption. The anti-nutritional effect of NSP's is often confounded by the fact that the above mentioned factors rarely can be separated. It is more likely that a combination of these factors will result in the overall anti-nutritional effect associated with NSP's.

The results also showed that enzyme supplementation to corn or wheat based diets improved all tested parameter cited above. Various reports suggest that, significant improvement can be made with the use of NSP's degraded enzyme combinations (Zanella et al. (1999), Cowieson and Adeola 2005, Meng and slominski, 2005).

The results of the current study evident also that feed intake was increased when low NSP cereal (corn) was substitute for high NSP cereal (wheat) and also due to supplementation of NSPase's enzymes in the broiler diets regardless of cereal type. This may due to that, with increasing intestinal viscosity the bird perceives a reduction in nutrient density and compensates by eating slightly more until a threshold is reached, which is likely in the region of $20 \mathrm{mPas}$, at which point the digest is too viscous for further compensatory increments in passage rate. The consequence is that when viscosity increases from 1 to 20 $\mathrm{mPas}$, the principal problem is a deterioration in FCR with little loss in gain as intake is able to compensate, whereas above $20 \mathrm{mPas}$ both gain and intake fall with further viscosity increments and FCR is doubly compromised. Thus, diets which generate viscosities in excess of $20 \mathrm{mPas}$ will have far more detrimental effects on performance than those that are below $10 \mathrm{mPas}$ (Bedford, 2014).

In the case of high viscosity diets, the effects of NSP'ases on both performance and health are therefore much more self-evident than in the case of low viscosity diets. In that regard, maize based diets rarely result in viscosities in excess of $10 \mathrm{mPas}$, and thus it is likely that viscosity plays only a minor role in the response to NSP'ases in such diets (Bedford, 2014). The resuls agree with Hessllman et al., (1981 and 1982) reproted an increase in feed intake due supplementation of enzyme in the broiler diets.

In this study, fat availability was more affected than effects on other nutrients by the enzyme supplementation. This is consistent with other studies (Yu et al., 2002), and may be due to that, bile salts are required for fat emulsification to form micelles (Erlinger, 1987). The viscosity caused by SDF in wheat depressed the fat emulsification and the enterohepatic circulation of bile salts (Cameron-Smith et al., 1994; Pasquier et al., 1996).Therefore; the effects of substituted wheat for corn and enzyme supplementation on fat availability were greater than effects on other nutrients.

The results of the current study demonstrated also that enzyme supplementation to low energy diets (by up to less $150 \mathrm{kcal} / \mathrm{kg}$ diet compared to the control) compensate for lowering energy level by increasing feed intake. This may partially due to the effect of physical constraint of viscosity on digesta flow rate that increased digesta residence time and thereby decreased feed intake and / or the effect of dietary energy level on feed intake. Leeson et al. (1996) showed that broiler feed intake increases linearly with decreasing dietary energy level. Albuquerque et al. (2003) also described reduction in feed intake due to higher dietary energy density. In addition, Leeson et al. (1996) found that broilers fed free-choice on diets with either 2700 or $3300 \mathrm{kcal}$ metabolizable energy/ $\mathrm{kg}$ presented the same growth rate and constant energy consumption. Also Juan-Louis (2007) reported that--In the reformulated diet, the energy level was reduced by $75 \mathrm{Kcal} \mathrm{ME}$. This may be the reason for increased feed intake. In this connection also Yu and Chung (2004) reported that adding adequate activity levels of $\alpha$ - amylase, $\beta$ - glucanase and Xylanase to broiler starter and grower corn-soya diets with $3 \%$ reduction in dietary ME allowed full restoration of growth performance comparable to those fed the adequate energy positive control. Cowieson and Masey (2013) found improvement in body weight gain of $6.3 \%$ associate with addition of Xylanase to the control diet. The birds that received the reduce energy diet supplemented with Xylanase had performance equivalent to the control group.

\section{CONCLUSION}

In conclusion, results of the current study demonstrated that the multi-carbohydrase enzyme preparation used in the current study was effective in viscosity reduction, which resulted in increased 
digestibility of fat, and AME in broiler chickens fed wheat-based diets. Also, the improvements in feed intake are at least of equal importance as the viscosity-reducing aspects.

\section{REFERENCES}

Acamovic, T. (2001) Commercial application of enzyme technology for poultry production. World's Poultry Science Journal, 57: 225 - 242.

Albuquerque, R.; D.E. Faria; O.M. Junqueira; D. Salvador; D.E. Faria, Filho and M.F. Rizzo (2003) . Effects of energy levels in finisher diets and slaughter age of on performance and carcass yield in broiler chickens. Brazilian Journal of Poultry Science, 5(2):99-104.

Anjum, M.S. and A.S. Chaudhry (2010) Using enzymes and organic acids in broiler diets. J. Poult. Sci., 47:97-105.

Annison, G. (1993). The role of wheat non-starch polysaccharides in broiler nutrition. Austral. J. Agri. Res., 44:405-422.

Annison, E.F.; D. Balnave; W.L. Bryden; Y. Mollah and A.M. Rogel (1987). Clarification of the relationship between digestible starch content and the metabolisable energy of Australian wheats. Br. Poult. Sci., 28:781-782.

AOAC (1990). Association of Analytical Chemists (1990). Methods of Analysis. 15th ed. Association of Analytical Chemists, Washington DC.

AOAC (1999). Association of official analytical chmestry. Animal Feeds - Official methods of Analysis Association of Official Analytical Chemists, (Washington, DC)

Bach Knudsen, K.E. (1996). Carbohydrate and lignin content of plant materials used in animal feeding. Animal Feed Science and Technology, 67:319-338.

Bedford, M.R. and H. Schulze (1998). Exogenous enzymes for pigs and Poultry (Review). Nutr. Res. Rev., 11:91-114.

Bedford, M. (2014) Enzymes to improve health and performance of non - ruminants. Eastern Nutrition Conference, 14-15 may 2014: Delta Guelph Hotel and Conference Center 50 stone RDW-Guelph Ontario - Canada.

Cameron-Smith, D.; G.R. Collier and K. O’Dea. (1994). Effects of soluble dietary fibre on the viscosity of gastrointestinal contents and the acute glycaemic response in the rat. Br. J. Nutr., 71:563-571.

Chabrol, E and R. Charonnat (1937). Presse Med., 69: 1713.

Chesson, A. (2001).Non-starch polysaccharide degrading enzymes in poultry diets: influence of ingredients on the selection of activities. World's Poultry Science Journal, 57: 251-263.

Choct, M. and G. Annison. (1992). Anti-nutritive effects of wheat pentosans in broiler-chickens: Role of viscosity and gut microflora. Br. Poult. Sci., 33:821-834.

Choct, M.; R.J. Hughes and M.R. Bedford (1999). Effect of xylanase on individual bird variation, starch digestion throughout the intestine, and ileal and caecal volatile fatty acid production in chickens fed wheat. British Poultry Science, 40:419-422.

Choct, M.; R.J. Hughes; J. Wang; M.R. Bedford; A.J. Morgan and G. Annison (1996). Increased small intestinal fermentation is partly responsible for the anti-nutritive activity of non-starch polysaccharides in chickens. British Poultry Science, 37:609-621.

Choct, M. (2001) Enzymes supplementation of poultry diets based on viscous cereals. In: Enzymes in farm animal nutrition (Bedford, M.R. and Partridge, G.G., editors. pp 145 - 160. CABI publishing, United Kingdom.

Classen, H.; T.A. Scott; G.G. Irish; P. Hucl; M. Swift and M.R. Bedford (1995). The relationship of chemical and physical measurements to the apparent metabolizable energy (AME) of wheat when fed to broiler chickens with and without a wheat enzyme source. Proc. 10th Europ. Symp. Poult. Nutr. Antalya, Turkey.

Classen, H.L. (1996). Cereal grain starch and exogenous enzymes in poultry diets. Animal Feed Science and Technology, 62:21-27.

Cowan, W.D.; A. Korsbak; T. Hastrup and P.B. Rasmussen (1996). Influence of added microbial enzymes on energy and protein availability of selected feed ingredients. Animal Feed Science and Technology, 60:311-319.

Cowieson, A.J. and O. Adeola (2005). Carbohydrases, protease, and phytase have an additive beneficial effect on nutritionally marginal diets for broilers. Poultry Science, 84:1860-1868.

Cowieson, A.J. and H.V. Masey O'neill (2013) Effect of exogenous xylanase on performance, nutrient digestibility and caecal thermal profiles of broilers fed wheat - based diets. British Poultry Sci., 54 (3):346-354. 
Creswell, D.C. (1994). Upgrading the nutritional value of grains with the use of enzymes. Technical bulletin, American Soybean Association, 341 Orchard Road No. 11 - 03 Liat Towers, Singapore.

Dudley-Cash, W.A. (2001). Soybean meal source, added enzyme affect nutritional value forchicks. Feedstuffs, 73:41.

Duncan, D.B. (1955). Multiple ranges and Multiple F-test. Biometrics, 11: 1-42.

Dunn, N. (1996) Combating the pentosans in cereals. World poultry, 12 (1):24 - 25.

Doumas, B.T. and H.G. Biggs (1972). In standard methods of clinical chemistry. Quantitative colorimetric determination of albumin in serum or plasma. Academic press, New York, 7: 175.

Doumas, B.T.; D.D. Carter.; R.J. Peters and R. Schaffer (1981). Candidate reference method for determination of total protein in serum. 1 development and validation. Clin. Chem., 27:1642.

Erlinger, S. (1987). Physiology of bile secretion and entrohepatic circulation, p. 1557-1580. In (Ed. L. R. Johnson), Physiology of the Gastrointestinal Tract. Raven Press, New York.

Flegg. H.M. (1973). Determination of total cholesterol. Ann. Clin. Biochem., 10:79.

Hesselman, H.; K. Elwinger and S. Thomke (1982). Influence of increasing levels of $\beta$-glucanase on the productive value of barely diets for broiler chickens. Anim. Feed Sci. and Tech., 7:351-358.

Hessleman, H.; K. Elwinger; M. Nilsson and S. Thomke (1981). The effect of $\beta$-glucanase supplementation, stage of ripeness and storage treatments of barely in diets fed to broiler chickens. Poult. Sci., 60:2664-2671.

Hill, F.W. and D.L. Anderson (1958). Comparison of metabolizable energy and productive energy determinations with growing chicks. J. Nutr., 64: 587.

Hubbard Broiler management Guide, (1999) Hubbard - ISA, 119Avenue des axe 69427, Lyon Codex 03 - France.

Iji, P.A.; K. Khumalo; S. Slippers and R.M. Gous (2003). Intestinal function and body growth of broiler chickens on diets based on maize dried at different temperatures and supplemented with a microbial enzyme. Reprod. Nutr. Dev., 43:77-90.

Jacobsen, P.E.; S.G. Kirston and H. Nelson (1960). Digestibility trials with poultry. 322 berthing fraforsgs laboratories udgivet of stants Hugyrbugvalg- Kabenhavn.

Juan-Louis, Fourie (2007). The effects of a multiple-enzyme combination in maize-soya diets for broiler chickens. M.Sc Thesis, Stellenbosch University of Stellenbosch, USA.

Leeson, S.; L. Caston and J.D. Summers (1996) Broiler response to diet energy. Poultry Science, 75(4):529-535.

Leeson, S. and J.D. Summers (2005). Commercial Poultry Nutrition. 3rd ed. University Books, Guelph, Ontario, Canada.

Mathlouthi, N.; J.P. Lallès; P. Lepercq; C. Juste and M. Larbier (2002). Xylanase and $\beta$-glucanase supplementation improve conjugated bile acid fraction in intestinal contents and increase villus size of small intestine wall in broiler chickens fed a rye-based diet. Journal of Animal Science, 80:2773-2779.

Meng, X. and B.A. Slominski (2005). Nutritive values of corn, soyabean meal, canola meal, and peas for broiler chickens as affected by a multicarbohydrase preparation of cell wall degrading enzymes. Poultry Science, 84:1242-1251.

Pasquier, B.; M. Armand; F. Guillon; C. Castelain; P. Borel; J.L. Barry; G. Pieroni and D. Lairon (1996). Viscous soluble dietary fibers alter emulsification and lipolysis of triacylglycerols in duodenal medium in vitro. J. Nutr. Biochem, 7:293-302.

Pirgozliev, V.R.; C.L. Birch; S.P. Rose; P.S. Kettlewell and M.R. Bedford (2003) Chemical composition and the nutritive quality of different wheat cultivars for broiler chickens. Br. Poult. Sci., 44:464-475.

Reitman, S. and S. Frankel (1957). AST and ALT transaminases determination in serum and plasma. Am.J. Clin. Path., 28.56.

SAS (1990). SAS/STAT User's Guide: Statistics, Release 6.04, SAS Institute, Inc., Cary, NC., USA.

Schutte, J.B.; J. de Jong and D.J. Langhout (1995) Effect of a xylanase enzyme supplementation to wheat- based diets in broiler chicks in relation to dietary factors. Proceedings of the second European Symposium on Feed Enzymes, Noordwijkerhout, Netherlands, pp.95-101.

Sheppy, C. (2001). The current feed enzyme market and likely trents. In: M. R. Bedford and G. G. Partridge. Enzymes in Farm Animal Nutrititon. CABI Publishing, pp. 1- 10.

Simon, O. (1998). The mode of action of NSP hydrolyzing enzymes in the gastrointestinal tract. J. Anim. Feed Sci., 7:115-123.

Sibbald, L.R.; J.D. Sommer and S.J. Slinger (1960). Factors' affecting the metabolizable energy content of poultry feeds. Poultry Sci., 39:544-556.

Smeets, N.; F. Nuyen; L. Van Campenhout and T. Niewold (2014) Variability in the in vitro degradation of non-starch polysaccharides from wheat by feed enzymes. Anim. Feed Sci. Technol., 187:110-114. 
Van Der Klis, C.; W. Scheele and C. Kwakernaak (1995). Wheat characteristics related to its feeding value and to the response of enzymes. Proceeding of the 10th European Symposium on Poultry Nutrition. Antalya, Turkey.

Ward, N.E (1995). With dietary modifications, wheat can be used for poultry. Feedstuffs 7 Aug., $14-16$.

Yu, B.I. and T.K. Chunge (2004) Effect of multiple-enzyme mixtures on growth performance of broilers fed corn-soybean meal diets. J. Appl. Poult. Res., 13:178-182.

Yu, B.; Y.M. Sun and P.W S. Chiou (2002). Effects of glucanase inclusion in a de-hulled barley diet on the growth performance and nutrient digestion of broiler chickens. Anim. Feed Sci. Technol. 102:3552.

Zanella, Sakomura, N. K.; F.G. Silversides; A. Fiqueirdo and M. Pack (1999). Effect of enzyme supplementation of broiler diets based on corn and soybeans. Poult. Sci., 78:561-568. 
Table (1). Composition and chemical analyses of the experimental diets used during 7-14 days of age (starter period).

\begin{tabular}{|c|c|c|c|c|c|c|}
\hline Ingredients & $\mathrm{T}_{1}$ & $\mathrm{~T}_{2}$ & $\mathrm{~T}_{3}$ & $\mathrm{~T}_{4}$ & $\mathrm{~T}_{5}$ & $\mathrm{~T}_{6}$ \\
\hline yellow corn & 59.5 & 60.3 & 58.35 & 14.55 & 12.65 & 00.00 \\
\hline Soybean meal $44 \%$ & 25.2 & 28.0 & 28.8 & 15.6 & 18.95 & 19.0 \\
\hline Corn gluten meal $60 \%$ & 7.6 & 5.6 & 4.9 & 8.0 & 5.55 & 4.00 \\
\hline Wheat & --- & --- & --- & 50.0 & 50.7 & 63.72 \\
\hline Wheat bran & 1.95 & 1.9 & 3.65 & 2.95 & 4.05 & 5.06 \\
\hline Di Calcium Phosphate & 1.95 & 1.9 & 1.92 & 2.07 & 2.00 & 1.82 \\
\hline Limestone & 1.2 & 1.15 & 1.22 & 1.25 & 1.2 & 1.00 \\
\hline Premix* & 0.3 & 0.3 & 0.3 & 0.3 & 0.3 & 0.3 \\
\hline $\mathrm{NaCl}$ & 0.55 & 0.5 & 0.53 & 0.5 & 0.5 & 0.45 \\
\hline L- Lysine HCL & 0.3 & 0.2 & 0.18 & 0.52 & 0.41 & 0.39 \\
\hline Dl- Methionine & 0.1 & 0.15 & 0.15 & 0.16 & 0.19 & 0.26 \\
\hline Soya oil & 1.35 & --- & --- & 4.1 & 3.5 & 4.0 \\
\hline Total & 100.00 & 100.00 & 100.00 & 100.00 & 100.00 & 100.00 \\
\hline \multicolumn{7}{|l|}{ Calculated Analysis ${ }^{* *}$} \\
\hline C.P \% & 21.0 & 21.0 & 21.0 & 21.0 & 21.0 & 21.0 \\
\hline $\mathrm{ME}(\mathrm{Kcal} / \mathrm{Kg})$ & 2988 & 2888 & 2837 & 2987 & 2888 & 2843 \\
\hline Calcium $\%$ & 0.95 & 0.93 & 0.97 & 1.0 & 0.97 & 0.9 \\
\hline Av. Phosphorus \% & 0.50 & 0.50 & 0.50 & 0.52 & 0.52 & 0.49 \\
\hline Lysine $\%$ & 1.2 & 1.19 & 1.2 & 1.18 & 1.17 & 1.17 \\
\hline Methionine \% & 0.51 & 0.54 & 0.54 & 0.53 & 0.54 & 0.54 \\
\hline Meth+Cys \% & 0.84 & 0.83 & 0.84 & 0.86 & 0.86 & 0.88 \\
\hline \multicolumn{7}{|l|}{ Determined Analysis } \\
\hline C.P \% & 22.14 & 22.14 & 22.20 & 22.04 & 22.07 & 22.18 \\
\hline C.F & 4.62 & 4.77 & 4.94 & 3.92 & 4.14 & 4.12 \\
\hline E.E & 4.89 & 3.54 & 3.49 & 5.86 & 5.17 & 5.16 \\
\hline GE(Kcal/Kg) & 4047 & 3979 & 3970 & 4017 & 3977 & 4064 \\
\hline
\end{tabular}


Egyptian J. Nutrition and Feeds (2015)

Table (2). Composition and chemical analyses of the experimental diets used during grower period (15 - 28 days of age).

\begin{tabular}{|c|c|c|c|c|c|c|}
\hline Ingredients & $\mathrm{T}_{1}$ & $\mathrm{~T}_{2}$ & $\mathrm{~T}_{3}$ & $\mathrm{~T}_{4}$ & $\mathrm{~T}_{5}$ & $\mathrm{~T}_{6}$ \\
\hline Yellow corn & 61.1 & 63.55 & 60.5 & 24.5 & 25.5 & 14.5 \\
\hline Soybean meal, $44 \%$ & 24.0 & 23.9 & 23.6 & 8.25 & 10.9 & 5.9 \\
\hline Corn gluten meal $60 \%$ & 4.9 & 4.7 & 4.55 & 9.2 & 7.5 & 8.8 \\
\hline Wheat & --- & --- & --- & 48 & 48.17 & 60.12 \\
\hline Wheat bran & 2.6 & 2.5 & 5.7 & 1.9 & 1.38 & 4.0 \\
\hline Di Calcium Phosphate & 1.85 & 1.88 & 1.8 & 2.0 & 2.0 & 1.9 \\
\hline Limestone & 1.15 & 1.13 & 1.20 & 1.11 & 1.11 & 1.2 \\
\hline premix* & 0.3 & 0.3 & 0.3 & 0.3 & 0.3 & 0.3 \\
\hline $\mathrm{NaCl}$ & 0.45 & 0.45 & 0.45 & 0.43 & 0.42 & 0.43 \\
\hline Dl- Methionine & 0.16 & 0.15 & 0.15 & 0.16 & 0.17 & 0.18 \\
\hline L- Lysine- HCL & 0.24 & 0.24 & 0.25 & 0.65 & 0.55 & 0.67 \\
\hline Soya oil & 3.25 & 1.2 & 1.5 & 3.5 & 2.0 & 2.0 \\
\hline Total & 100.00 & 100.00 & 100.00 & 100.00 & 100.00 & 100.00 \\
\hline \multicolumn{7}{|l|}{ Calculated Analysis ${ }^{* *}$} \\
\hline C.P \% & 19.00 & 19.00 & 19.00 & 19.00 & 19.00 & 19.00 \\
\hline $\mathrm{ME}(\mathrm{Kcal} / \mathrm{Kg})$ & 3083 & 2983 & 2935 & 3083 & 2982 & 2935 \\
\hline Calcium $\%$ & 0.91 & 0.91 & 0.92 & 0.95 & 0.94 & 0.96 \\
\hline Av. Phosphorus\% & 0.48 & 0.49 & 0.48 & 0.49 & 0.49 & 0.49 \\
\hline Lysine \% & 1.1 & 1.1 & 1.1 & 1.1 & 1.1 & 1.1 \\
\hline Methionine \% & 0.52 & 0.51 & 0.51 & 0.51 & 0.51 & 0.51 \\
\hline Meth+Cys \% & 0.84 & 0.83 & 0.84 & 0.86 & 0.86 & 0.88 \\
\hline \multicolumn{7}{|l|}{ Determined Analysis } \\
\hline C.P \% & 20.15 & 20.16 & 20.28 & 20.01 & 20.03 & 20.04 \\
\hline C.F & 4.62 & 4.70 & 4.94 & 3.71 & 3.82 & 3.80 \\
\hline E.E & 6.78 & 4.84 & 5.09 & 5.65 & 4.16 & 3.80 \\
\hline $\mathrm{GE}(\mathrm{Kcal} / \mathrm{Kg})$ & 4103 & 4010 & 4023 & 3993 & 3915 & 3987 \\
\hline
\end{tabular}


Egyptian J. Nutrition and Feeds (2015)

Table (3). Composition and chemical analyses of the experimental diets used during finisher period (29-42 days of age).

\begin{tabular}{|c|c|c|c|c|c|c|}
\hline Ingredients & $\mathrm{T}_{1}$ & $\mathrm{~T}_{2}$ & $\mathrm{~T}_{3}$ & $\mathrm{~T}_{4}$ & $\mathrm{~T}_{5}$ & $\mathrm{~T}_{6}$ \\
\hline Yellow corn & 65 & 63.30 & 60.3 & 25.8 & 25.45 & 15.5 \\
\hline Soybean meal, $44 \%$ & 23.05 & 23.1 & 23.6 & 4.05 & 6.5 & 5.00 \\
\hline Corn gluten meal $60 \%$ & 4.2 & 3.55 & 3.0 & 10.15 & 8.2 & 7.9 \\
\hline Wheat & --- & --- & --- & 51.65 & 50.0 & 60.1 \\
\hline Wheat bran & --- & 3.05 & 5.85 & --- & 2.15 & 3.55 \\
\hline Di Calcium Phosphate & 1.74 & 1.71 & 1.7 & 1.87 & 1.87 & 1.9 \\
\hline Limestone & 1.1 & 1.10 & 1.12 & 1.08 & 1.07 & 1.07 \\
\hline premix* & 0.3 & 0.3 & 0.3 & 0.3 & 0.3 & 0.3 \\
\hline $\mathrm{NaCl}$ & 0.45 & 0.45 & 0.45 & 0.42 & 0.43 & 0.43 \\
\hline Dl- Methionine & 0.18 & 0.18 & 0.18 & 0.16 & 0.2 & 0.23 \\
\hline L- Lysine- HCL & 0.23 & 0.21 & 0.2 & 0.72 & 0.63 & 0.67 \\
\hline Soya oil & 3.75 & 3.05 & 3.3 & 3.8 & 3.2 & 3.35 \\
\hline Total & 100.00 & 100.00 & 100.00 & 100.00 & 100.00 & 100.00 \\
\hline \multicolumn{7}{|l|}{ Calculated Analysis ** } \\
\hline C.P \% & 18.00 & 18.00 & 18.00 & 18.00 & 18.00 & 18.00 \\
\hline $\mathrm{ME}(\mathrm{Kcal} / \mathrm{Kg})$ & 3175 & 3075 & 3023 & 3176 & 3075 & 3023 \\
\hline Calcium $\%$ & 0.87 & 0.86 & 0.87 & 0.86 & 0.87 & 0.91 \\
\hline Av. Phosphorus\% & 0.45 & 0.45 & 0.46 & 0.46 & 0.47 & 0.48 \\
\hline Lysine \% & 1.06 & 1.05 & 1.06 & 1.04 & 1.02 & 1.02 \\
\hline Methionine \% & 0.53 & 0.53 & 0.52 & 0.51 & 0.53 & 0.55 \\
\hline Meth+Cys \% & 0.82 & 0.82 & 0.82 & 0.83 & 0.87 & 0.88 \\
\hline \multicolumn{7}{|l|}{ Determined analysis } \\
\hline C.P \% & 19.13 & 19.15 & 19.30 & 19.05 & 19.00 & 19.09 \\
\hline C.F & 4.40 & 4.67 & 4.90 & 3.42 & 3.71 & 3.70 \\
\hline E.E & 7.36 & 6.65 & 6.83 & 5.97 & 5.37 & 5.15 \\
\hline $\mathrm{GE}(\mathrm{Kcal} / \mathrm{Kg})$ & 4116 & 4082 & 4090 & 4000 & 3962 & 3936 \\
\hline
\end{tabular}


Egyptian J. Nutrition and Feeds (2015)

Table (4). Effect of cereal type and enzyme supplementation on performance of broiler chicks.

\begin{tabular}{|c|c|c|c|c|c|c|c|c|c|c|c|c|}
\hline \multirow{2}{*}{$\begin{array}{l}\text { Items } \\
\text { Treatments } \\
\text { Corn }\end{array}$} & \multicolumn{4}{|c|}{ Feed Consumption } & \multicolumn{4}{|c|}{ Body Weight Gain } & \multicolumn{4}{|c|}{ Feed Conversion Ratio } \\
\hline & Starter & Grower & Finisher & Total & Starter & Grower & Finisher & Total & Starter & Grower & Finisher & Total \\
\hline \multirow{2}{*}{$\mathrm{C}+$} & $374 a$ & $1643 a$ & $2014 a$ & $4031 \mathrm{a}$ & $284 \mathrm{a}$ & $959 \mathrm{a}$ & 1002 & $2246 \mathrm{a}$ & 1.33 & $1.72 b$ & 2.04 & $1.79 \mathrm{~b}$ \\
\hline & +0.43 & +3.02 & +2.17 & +5.61 & +4.26 & +10.43 & +17.05 & +13.68 & +0.02 & +0.01 & +0.04 & +0.01 \\
\hline \multirow{2}{*}{$\mathrm{C}$} & $370 \mathrm{~b}$ & $1621 b$ & $1995 b$ & $3986 b$ & $272 b$ & $922 b$ & 983 & $2176 b$ & 1.38 & $1.78 \mathrm{a}$ & 2.11 & $1.84 \mathrm{a}$ \\
\hline & +0.28 & +1.90 & +1.91 & +3.53 & +4.43 & +14.06 & +24.1 & +18.5 & +0.02 & +0.03 & +0.05 & +0.01 \\
\hline SIG & $*$ & $*$ & $*$ & * & $*$ & * & N.S & $*$ & N.S & $*$ & N.S & $*$ \\
\hline \multicolumn{13}{|l|}{ Wheat } \\
\hline \multirow{2}{*}{$\mathrm{W}+$} & 367 & $1633 a$ & $1989 a$ & $3990 a$ & $269 a$ & $937 \mathrm{a}$ & $896 a$ & $2102 a$ & $1.37 \mathrm{~b}$ & $1.74 b$ & $2.27 \mathrm{~b}$ & $1.90 \mathrm{~b}$ \\
\hline & +1.35 & +6.75 & +1.03 & +6.49 & +2.59 & +5.64 & +10.44 & +8.95 & +0.03 & +0.01 & +0.03 & +0.01 \\
\hline \multirow{2}{*}{$\mathrm{W}$} & 364 & $1603 b$ & $1967 b$ & $3934 b$ & $251 \mathrm{~b}$ & $894 b$ & $806 b$ & $1951 b$ & $1.47 \mathrm{a}$ & $1.80 \mathrm{a}$ & $2.53 \mathrm{a}$ & $2.02 \mathrm{a}$ \\
\hline & +1.02 & +7.74 & +3.33 & +3.98 & +4.24 & +10.44 & +20.71 & +16.73 & +0.03 & +0.02 & +0.06 & +0.02 \\
\hline SIG & N.S & $*$ & $*$ & $*$ & $*$ & $*$ & $*$ & $*$ & $*$ & $*$ & $*$ & $*$ \\
\hline \multicolumn{13}{|l|}{ Cereal sources } \\
\hline \multirow[t]{2}{*}{ (5) } & 370 & $1621 \mathrm{a}$ & $1995 \mathrm{a}$ & $3986 a$ & $272 \mathrm{a}$ & $922 \mathrm{a}$ & $983 \mathrm{a}$ & $2175 a$ & $1.38 \mathrm{~b}$ & 1.78 & $2.11 \mathrm{~b}$ & $1.84 \mathrm{~b}$ \\
\hline & +0.28 & +1.90 & +1.91 & +3.53 & +4.43 & +14.06 & +24.11 & +18.5 & +0.02 & +0.03 & +0.05 & +0.01 \\
\hline \multirow{2}{*}{$\mathrm{W}$} & 364 & $1603 b$ & $1967 b$ & $3934 b$ & $251 \mathrm{~b}$ & 894 b & $807 \mathrm{~b}$ & $1951 \mathrm{~b}$ & $1.47 \mathrm{a}$ & 1.80 & $2.53 \mathrm{a}$ & $2.02 \mathrm{a}$ \\
\hline & +1.02 & +7.74 & +3.33 & +3.98 & +4.23 & +10.44 & +20.7 & +16.7 & +0.03 & +0.02 & +0.06 & +0.02 \\
\hline SIG & N.S & $*$ & $*$ & $*$ & $*$ & $*$ & $*$ & $*$ & $*$ & N.S & $*$ & $*$ \\
\hline
\end{tabular}


Egyptian J. Nutrition and Feeds (2015)

Table (5). Effect of low energy diets supplemented by enzymes cocktail on performance of broiler chicks.

\begin{tabular}{|c|c|c|c|c|c|c|c|c|c|c|c|c|}
\hline \multirow{2}{*}{$\begin{array}{l}\text { Items } \\
\text { Treatments }\end{array}$} & \multicolumn{4}{|c|}{ Feed Intake } & \multicolumn{4}{|c|}{ Body Weight Gain } & \multicolumn{4}{|c|}{ Feed Conversion Ratio } \\
\hline & Starter & Grower & Finisher & Total & Starter & Grower & Finisher & Total & Starter & Grower & Finisher & Total \\
\hline \multirow{2}{*}{$\mathrm{C}$} & $370 b$ & $1621 b$ & $1995 d$ & $3986 c$ & $272 \mathrm{a}$ & $922 \mathrm{ab}$ & $983 a$ & $2176 \mathrm{a}$ & $1.38 \mathrm{~b}$ & $1.78 b$ & $2.11 \mathrm{~b}$ & $1.84 \mathrm{c}$ \\
\hline & +0.28 & +1.90 & +1.91 & +3.53 & +4.43 & +14.06 & +24.11 & +18.52 & +0.02 & +0.02 & +0.05 & +0.01 \\
\hline \multirow{2}{*}{ LC100+ } & $372 b$ & $1618 b$ & $2031 \mathrm{c}$ & $4021 b$ & $274 \mathrm{a}$ & $926 \mathrm{ab}$ & $979 a$ & $2179 a$ & $1.38 \mathrm{~b}$ & $1.76 b$ & $2.14 b$ & $1.85 \mathrm{c}$ \\
\hline & +3.45 & +5.35 & +3.59 & +9.41 & +4.93 & +11.97 & +21.50 & +18.11 & +0.03 & +0.02 & +0.05 & +0.02 \\
\hline \multirow{2}{*}{ Lc150+ } & $367 b c$ & $1652 \mathrm{a}$ & $2055 b$ & $4075 a$ & $254 b$ & $950 \mathrm{a}$ & $974 a$ & $2177 \mathrm{a}$ & $1.47 \mathrm{a}$ & $1.76 \mathrm{~b}$ & $2.19 \mathrm{~b}$ & $1.89 \mathrm{~b}$ \\
\hline & +0.16 & +4.40 & +0.95 & +5.38 & +4.12 & +13.42 & +21.12 & +22.31 & +0.03 & +0.02 & +0.05 & +0.02 \\
\hline \multirow{2}{*}{ W } & $364 c$ & $1603 c$ & $1967 \mathrm{e}$ & $3934 d$ & $251 b$ & 894 b & $807 \mathrm{~b}$ & $1951 b$ & $1.47 \mathrm{a}$ & $1.80 \mathrm{a}$ & $2.53 \mathrm{a}$ & $2.02 \mathrm{a}$ \\
\hline & +1.02 & +7.74 & +3.33 & +3.98 & +4.23 & +10.44 & +20.71 & +16.73 & +0.03 & +0.02 & +0.06 & +0.01 \\
\hline \multirow{2}{*}{ LW100+ } & $370 b$ & $1623 b$ & $2080 a$ & $4074 a$ & $254 b$ & $911 \mathrm{ab}$ & $832 b$ & $1998 b$ & $1.48 \mathrm{a}$ & $1.80 \mathrm{a}$ & $2.54 \mathrm{a}$ & $2.03 \mathrm{a}$ \\
\hline & +0.53 & +1.55 & +10.52 & +12.23 & +4.74 & +14.71 & +19.27 & +16.36 & +0.02 & +0.02 & +0.06 & +0.02 \\
\hline \multirow{2}{*}{ LW150+ } & $384 a$ & $1617 b$ & $1987 d$ & $3989 c$ & $262 b$ & $890 b$ & $811 b$ & $1964 b$ & $1.50 \mathrm{a}$ & $1.88 \mathrm{a}$ & $2.48 \mathrm{a}$ & $2.04 \mathrm{a}$ \\
\hline & +1.07 & +3.02 & +2.74 & +6.67 & +5.27 & +10.54 & +19.45 & +16.14 & +0.03 & +0.02 & +0.06 & +0.01 \\
\hline SIG & * & $*$ & $*$ & * & $*$ & $*$ & $*$ & $*$ & $*$ & $*$ & * & * \\
\hline
\end{tabular}


Table (6). Effect cereal type and enzyme supplementation on nutrients digestibility and apparent metabolizable energy values.

\begin{tabular}{llllllll}
\hline $\begin{array}{l}\text { Items } \\
\text { Treatments }\end{array}$ & CF & EE & CP & NFE & OM & AME & AMEn \\
\hline $\mathrm{C}+$ & 27.4 & $82.9 \mathrm{a}$ & 96.5 & 83.7 & 84.3 & 3494 & 3349 \\
& +1.86 & +0.85 & +0.28 & +1.10 & +0.86 & +33.1 & +027.7 \\
$\mathrm{C}$ & 23.8 & $80.6 \mathrm{~b}$ & 95.9 & 81.1 & 82.2 & 3438 & 3308 \\
$\mathrm{SIG}$ & +2.15 & +1.05 & +0.39 & +1.18 & +0.99 & +43.0 & +34.4 \\
$\mathrm{~W}+$ & $\mathrm{N} . \mathrm{S}$ & $*$ & $\mathrm{~N} . \mathrm{S}$ & $\mathrm{N} . \mathrm{S}$ & $\mathrm{N} . \mathrm{S}$ & $\mathrm{N} . \mathrm{S}$ & $\mathrm{N} . \mathrm{S}$ \\
& $29.1 \mathrm{a}$ & $82.0 \mathrm{a}$ & 96.1 & $85.8 \mathrm{a}$ & $85.6 \mathrm{a}$ & $3544 \mathrm{a}$ & $3403 \mathrm{a}$ \\
$\mathrm{W}$ & +1.13 & +1.01 & +0.27 & +0.73 & +0.57 & +26.0 & +20.4 \\
$\mathrm{SIG}$ & $23.1 \mathrm{~b}$ & $77.2 \mathrm{~b}$ & 95.6 & $82.4 \mathrm{~b}$ & $82.5 \mathrm{~b}$ & $3419 \mathrm{~b}$ & $3298 \mathrm{~b}$ \\
$\mathrm{C}$ & +2.28 & +1.26 & +0.29 & +0.84 & +0.72 & +32.8 & +25.2 \\
& $*$ & $*$ & $\mathrm{~N} . \mathrm{S}$ & $*$ & $*$ & $*$ & $*$ \\
$\mathrm{~W}$ & 23.8 & 80.6 & 95.9 & 81.1 & 82.2 & 3438 & 3308 \\
$\mathrm{SIG}$ & +2.15 & +1.05 & +0.39 & +1.18 & +0.99 & +43.0 & +34.4 \\
& 23.1 & 77.2 & 95.6 & 82.4 & 82.5 & 3419 & 3298 \\
& +2.28 & +1.26 & +0.29 & +0.84 & +0.72 & +32.8 & +25.2 \\
\hline
\end{tabular}

Table (7). Effect of low energy diets supplemented by enzymes cocktail on nutrients digestibility and apparent metabolizable energy values.

\begin{tabular}{lccccccc}
\hline Items & CF & EE & D.CP & NFE & OM & AME & AMEn \\
Treatments & 23.8 & $80.6 \mathrm{a}$ & $95.9 \mathrm{ab}$ & $81.1 \mathrm{~b}$ & $82.2 \mathrm{~b}$ & 3438 & 3308 \\
$\mathrm{C}$ & +2.15 & +1.04 & +0.39 & +1.18 & +0.99 & +43.0 & +34.4 \\
& 24.7 & $80.1 \mathrm{a}$ & $96.7 \mathrm{a}$ & $86.1 \mathrm{a}$ & $85.6 \mathrm{a}$ & 3480 & 3321 \\
$\mathrm{LC} 100+$ & +1.71 & +0.57 & +0.22 & +0.41 & +0.36 & +23.2 & +19.6 \\
& 26.3 & $79.4 \mathrm{a}$ & $96.3 \mathrm{ab}$ & $83.3 \mathrm{~b}$ & $83.5 \mathrm{ab}$ & 3420 & 3272 \\
$\mathrm{LC} 150+$ & +1.55 & +0.71 & +0.26 & +0.49 & +0.42 & +16.9 & +13.8 \\
& 23.1 & $77.2 \mathrm{~b}$ & $95.6 \mathrm{~b}$ & $82.4 \mathrm{~b}$ & $82.5 \mathrm{~b}$ & 3419 & 3298 \\
$\mathrm{~W}$ & +2.28 & +1.26 & +3.02 & +0.84 & +0.72 & +32.8 & +25.2 \\
& 26.3 & $73.9 \mathrm{c}$ & $96.3 \mathrm{ab}$ & $82.7 \mathrm{~b}$ & $82.8 \mathrm{~b}$ & 3418 & 3289 \\
$\mathrm{LW}+$ & +2.40 & +1.60 & +0.23 & +1.05 & +0.92 & +32.6 & +28.5 \\
$\mathrm{LW} 150+$ & 26.8 & $73.4 \mathrm{c}$ & $95.7 \mathrm{~b}$ & $83.8 \mathrm{~b}$ & $83.7 \mathrm{ab}$ & 3438 & 3299 \\
& +1.21 & +1.61 & +0.23 & +0.99 & +0.83 & +29.9 & +25.6 \\
SIG & $\mathrm{N} . \mathrm{S}$ & $*$ & $*$ & $*$ & $*$ & $\mathrm{~N} . \mathrm{S}$ & $\mathrm{Ns}$ \\
\hline
\end{tabular}


Egyptian J. Nutrition and Feeds (2015)

Table (8). Effect of cereal type and enzyme supplementation on gross energy efficiency.

\begin{tabular}{|c|c|c|c|c|c|c|c|c|c|c|c|c|}
\hline \multirow{2}{*}{$\begin{array}{l}\text { Items } \\
\text { Treatments }\end{array}$} & \multicolumn{12}{|c|}{ Gross Energy conversion ratio } \\
\hline & GIS & GIG & GIF & GIT & GS & GG & GF & GT & GCS & GCG & GCF & GCT \\
\hline \multicolumn{13}{|l|}{ Corn } \\
\hline \multirow{2}{*}{$\mathrm{C}+$} & 1514 & 6739 & 8287 & 16542 & $284 \mathrm{a}$ & 959 & 1002 & $2246 a$ & $5.32 b$ & 7.03 & 8.26 & $7.36 \mathrm{~b}$ \\
\hline & +9.44 & +67.50 & +48.80 & +124.8 & +1.85 & +13.5 & +7.09 & +12.00 & +0.05 & +0.12 & +0.06 & +0.02 \\
\hline \multirow{2}{*}{$\mathrm{C}$} & 1497 & 6649 & 8211 & 16358 & $272 b$ & 921 & 982 & $2175 b$ & $5.50 \mathrm{a}$ & 7.21 & 8.35 & $7.51 \mathrm{a}$ \\
\hline & +6.18 & +42.50 & +42.8 & +78.60 & +3.17 & +6.96 & +3.17 & +1.20 & +0.04 & +0.03 & +0.06 & +0.03 \\
\hline Sig & NS & NS & NS & NS & $*$ & NS & NS & $*$ & $*$ & NS & NS & $*$ \\
\hline \multicolumn{13}{|l|}{ Wheat } \\
\hline \multirow{2}{*}{$\mathrm{W}+$} & 1489 & 6522 & 7956 & 15966 & 266 & $937 \mathrm{a}$ & $896 a$ & $2102 \mathrm{a}$ & 5.53 & 6.96 & $8.88 b$ & $7.59 b$ \\
\hline & +25.50 & +146.40 & +22.2 & +127.6 & +5.17 & +3.21 & +9.90 & +9.84 & +0.09 & +0.16 & +0.11 & +0.03 \\
\hline \multirow{2}{*}{ W } & 1461 & 6402 & 7869 & 15732 & 251 & $894 b$ & $807 b$ & $1951 b$ & 5.83 & 7.16 & $9.75 \mathrm{a}$ & $8.06 \mathrm{a}$ \\
\hline & +22.28 & +167.9 & +72.4 & +86.2 & +3.48 & +10.17 & +2.00 & +8.45 & +0.16 & +0.15 & +0.08 & +0.06 \\
\hline Sig & NS & NS & NS & NS & NS & $*$ & $*$ & $*$ & NS & NS & $*$ & $*$ \\
\hline & 1497 & 6649 & $8211 \mathrm{a}$ & $16358 \mathrm{a}$ & $272 a$ & 921 & $982 \mathrm{a}$ & $2175 a$ & 5.50 & 7.21 & $8.35 b$ & $7.51 \mathrm{~b}$ \\
\hline $\mathrm{C}$ & +6.18 & +42.50 & +42.8 & +78.60 & +3.17 & +6.96 & +3.17 & +1.20 & +0.04 & +0.03 & +0.06 & +0.03 \\
\hline \multirow{2}{*}{ W } & 1461 & 6402 & $7869 b$ & $15732 b$ & $251 b$ & 894 & $807 b$ & $1951 b$ & 5.83 & 7.16 & $9.75 a$ & $8.06 \mathrm{a}$ \\
\hline & +22.28 & +167.9 & +72.4 & +86.2 & +3.48 & +10.17 & +2.00 & +8.45 & +0.16 & +0.15 & +0.08 & +0.06 \\
\hline Sig & $\mathrm{Ns}$ & N.S & $*$ & $*$ & $*$ & N.S & $*$ & $*$ & N.S & N.S & $*$ & $*$ \\
\hline
\end{tabular}

GIS = Gross Energy Intake Starter, GIG = Gross Energy Intake Grower, GIF = Gross Energy Intake Finisher, GIT = Gross Energy Intake Total

GCS = Gross Energy Conversion Starter, GCG = Gross Energy Conversion Grower, GCF = Gross Energy Conversion Finisher, GCT $=$ Gross Energy Conversion Total 
Egyptian J. Nutrition and Feeds (2015)

Table (9). Effect of low energy diets supplemented by enzymes cocktail on gross energy conversion ratio.

\begin{tabular}{|c|c|c|c|c|c|c|c|c|c|c|c|c|}
\hline \multirow{2}{*}{$\begin{array}{l}\text { Items } \\
\text { Treatments }\end{array}$} & \multicolumn{12}{|c|}{ Gross Energy conversion ratio } \\
\hline & GIS & GIG & GIF & GIT & GS & GG & GF & GT & GCS & GCG & $\mathrm{GCF}$ & GCT \\
\hline \multirow[t]{2}{*}{$\mathrm{C}$} & 1497 & 6649 & $8211 \mathrm{a}$ & $16358 \mathrm{ab}$ & $272 \mathrm{a}$ & $921 \mathrm{a}$ & $982 \mathrm{a}$ & $2175 a$ & $5.50 \mathrm{bc}$ & 7.21 & $8.35 b$ & $7.51 \mathrm{~b}$ \\
\hline & +6.18 & +42.50 & +42.8 & +78.60 & +3.17 & +6.96 & +3.17 & +1.20 & +0.04 & +0.03 & +0.06 & +0.03 \\
\hline \multirow{2}{*}{ LC100+ } & $1480 \mathrm{~b}$ & 6489.5 & $8289 a$ & $16258 \mathrm{abc}$ & $274 a$ & $926 a b$ & $979 a$ & $2179 a$ & $5.40 \mathrm{c}$ & 7.01 & $8.47 b$ & $7.46 \mathrm{~b}$ \\
\hline & +6.90 & +116.5 & +79.7 & +195.3 & +4.00 & +1.76 & +19.4 & +16.7 & +0.06 & +0.12 & +0.23 & +0.14 \\
\hline \multirow{2}{*}{ LC150+ } & $1458 b$ & 6647 & $8404 a$ & $16510 \mathrm{a}$ & $254 b$ & $950 \mathrm{ab}$ & $973 a$ & $2177 \mathrm{a}$ & $5.74 \mathrm{ab}$ & 7.00 & $8.64 b$ & $7.58 b$ \\
\hline & +3.50 & +96.20 & +20.10 & +116.3 & +4.36 & +10.3 & +5.78 & +7.00 & +0.08 & +0.09 & +0.06 & +0.05 \\
\hline \multirow{2}{*}{ W } & $1461 b$ & 6402 & $7869 b$ & $15732 \mathrm{c}$ & $251 \mathrm{~b}$ & $894 b$ & $807 b$ & $1951 \mathrm{c}$ & $5.83 \mathrm{ab}$ & 7.16 & $9.75 \mathrm{a}$ & $8.06 \mathrm{a}$ \\
\hline & +22.28 & +167.9 & +72.4 & +86.2 & +3.48 & +10.17 & +2.00 & +8.45 & +0.16 & +0.15 & +0.08 & +0.06 \\
\hline \multirow{2}{*}{ LW100+ } & $1471 b$ & 6355 & $8242 a$ & $16069 \mathrm{abc}$ & $254 b$ & $911 \mathrm{ab}$ & $832 b$ & $1997 b$ & $5.80 \mathrm{ab}$ & 6.98 & $9.91 \mathrm{a}$ & $8.05 a$ \\
\hline & +11.40 & +32.9 & +126.5 & +262.8 & +7.21 & +21.4 & +2.64 & +24.6 & +0.16 & +0.13 & +0.28 & +0.11 \\
\hline \multirow{2}{*}{ LW150+ } & $1560 \mathrm{a}$ & 6448 & $7822 \mathrm{~b}$ & $15831 \mathrm{c}$ & $262 \mathrm{ab}$ & $889 b$ & $812 b$ & $1964 b$ & $5.95 \mathrm{a}$ & 7.24 & $9.63 \mathrm{a}$ & $8.06 \mathrm{a}$ \\
\hline & +23.8 & +65.3 & +58.6 & +144.1 & +3.28 & +12.6 & +3.7 & +7.44 & +0.15 & +0.04 & +0.10 & +0.05 \\
\hline Sig & N.S & N.S & $*$ & $*$ & $*$ & $*$ & $*$ & $*$ & $*$ & N.S & $*$ & $*$ \\
\hline
\end{tabular}

GIS = Gross Energy Intake Starter, GIG = Gross Energy Intake Grower, GIF = Gross Energy Intake Finisher, GIT = Gross Energy Intake Total

GCS = Gross Energy Conversion Starter, GCG = Gross Energy Conversion Grower, GCF = Gross Energy Conversion Finisher, GCT = Gross Energy Conversion Total 
Egyptian J. Nutrition and Feeds (2015)

Table (10). Effect of cereal type and enzyme supplementation on protein conversion ratio.

\begin{tabular}{|c|c|c|c|c|c|c|c|c|c|c|c|c|}
\hline \multirow{2}{*}{$\begin{array}{l}\text { Items } \\
\text { Treatments }\end{array}$} & \multicolumn{12}{|c|}{ Protein conversion ratio } \\
\hline & PIS & PIG & PIF & PIT & GS & GG & GF & GT & PCS & PCG & PCF & PCT \\
\hline \multicolumn{13}{|l|}{ Corn } \\
\hline \multirow{2}{*}{$\mathrm{C}+$} & 82.8 & 331 & 385 & 799 & $284 a$ & 959 & 1002 & $2246 a$ & $0.28 \mathrm{~b}$ & 0.34 & 0.38 & $0.35^{b}$ \\
\hline & +0.51 & +3.33 & +2.33 & +6.02 & +1.85 & +13.5 & +7.09 & +12.00 & +0.01 & +0.00 & +0.00 & \pm 0.00 \\
\hline \multirow{2}{*}{$\mathrm{C}$} & 81.9 & 326 & 381 & 790 & $272 b$ & 921 & 982 & $2175 b$ & $0.30 \mathrm{a}$ & 0.35 & 0.38 & $0.36^{\mathrm{a}}$ \\
\hline & +0.34 & +2.00 & +2.08 & +3.92 & +3.17 & +6.96 & +3.17 & +1.20 & +0.01 & +0.00 & +0.00 & \pm 0.00 \\
\hline Sig & N.S & N.S & N.S & N.S & $*$ & N.S & N.S & $*$ & N.S & N.S & N.S & $*$ \\
\hline \multicolumn{13}{|l|}{ Wheat } \\
\hline \multirow{2}{*}{$\mathrm{W}+$} & 81.7 & 326 & 378 & 786 & 266 & $937 \mathrm{a}$ & $896 a$ & $2102 a$ & 0.30 & 0.34 & $0.42 b$ & $0.37 \mathrm{~b}$ \\
\hline & +1.40 & +7.33 & +1.20 & +6.43 & +5.17 & +3.21 & +9.90 & +9.84 & +0.00 & +0.01 & +0.01 & +0.00 \\
\hline \multirow{2}{*}{ W } & 80.1 & 321 & 374 & 775 & 251 & $894 b$ & $807 b$ & $1951 b$ & 0.31 & 0.35 & $0.46 a$ & $0.39 a$ \\
\hline & +1.22 & +8.41 & +3.38 & +4.33 & +3.48 & +10.17 & +2.00 & +8.45 & +0.01 & +0.00 & +0.00 & +0.00 \\
\hline Sig & N.S & N.S & N.S & N.S & N.S & N.S & N.S & $*$ & N.S & N.S & $*$ & $*$ \\
\hline \multicolumn{13}{|l|}{ Cereal sources } \\
\hline & 81.9 & 326 & 381 & 790 & $272 \mathrm{a}$ & 921 & $982 \mathrm{a}$ & $2175 a$ & $0.30 \mathrm{a}$ & 0.35 & $0.38 b$ & $0.36^{\mathrm{b}}$ \\
\hline $\mathrm{C}$ & +0.34 & +2.00 & +2.08 & +3.92 & +3.17 & +6.96 & +3.17 & +1.20 & +0.01 & +0.00 & +0.00 & \pm 0.00 \\
\hline W & 80.1 & 321 & 374 & 775 & $251 b$ & $894 b$ & $807 b$ & $1951 b$ & 0.31 & 0.35 & $0.46 \mathrm{a}$ & $\overline{0} .39^{\mathrm{a}}$ \\
\hline W & +1.22 & +8.41 & +3.38 & +4.33 & +3.48 & +10.17 & +2.00 & +8.45 & +0.01 & +0.00 & +0.00 & \pm 0.00 \\
\hline Sig & N.S & N.S & N.S & N.S & $*$ & N.S & $*$ & $*$ & N.S & N.S & $*$ & * \\
\hline
\end{tabular}

$P I S=$ Protein Intake Starter,$P I G=$ Protein Intake Grower, PIF = Protein Intake Finisher, $P I T=$ Protein Intake Total

$P C S=$ Protein Conversion Starter, PCG = Protein Conversion Grower, PCF = Protein Conversion Finisher, PCT = Protein Conversion Total 
Egyptian J. Nutrition and Feeds (2015)

Table (11). Effect of low energy diets supplemented by enzymes cocktail on protein conversion ratio.

\begin{tabular}{|c|c|c|c|c|c|c|c|c|c|c|c|c|}
\hline \multirow{2}{*}{$\begin{array}{l}\text { Items } \\
\text { Treatments }\end{array}$} & \multicolumn{12}{|c|}{ Protein conversion ratio } \\
\hline & PIS & PIG & PIF & PIT & GS & GG & GF & GT & PCS & PCG & PCF & PCT \\
\hline \multirow[t]{2}{*}{$\mathrm{C}$} & $81.9 \mathrm{ab}$ & 326 & $381 \mathrm{ab}$ & $790 \mathrm{ab}$ & $272 a$ & $921 \mathrm{ab}$ & $982 a$ & $2175 a$ & 0.30 & 0.35 & $0.38 \mathrm{~b}$ & $0.36 \mathrm{~b}$ \\
\hline & +0.34 & +2.00 & +2.08 & +3.92 & +3.17 & +6.96 & +3.17 & +1.20 & +0.01 & +0.00 & +0.00 & +0.00 \\
\hline \multirow{2}{*}{ LC100+ } & $82.3 \mathrm{ab}$ & 326 & $388 \mathrm{ab}$ & $797 \mathrm{ab}$ & $274 a$ & $926 a b$ & $979 a$ & $2179 a$ & 0.30 & 0.35 & $0.39 \mathrm{~b}$ & $0.36 \mathrm{~b}$ \\
\hline & +2.05 & +5.60 & +3.71 & +9.84 & +4.00 & +1.76 & +19.4 & +16.7 & +0.00 & +0.00 & +0.01 & +0.01 \\
\hline \multirow{2}{*}{ LC150+ } & $81.5 \mathrm{ab}$ & 335 & $396 a$ & $812 \mathrm{a}$ & $254 \mathrm{~b}$ & $950 \mathrm{a}$ & $973 a$ & $2177 \mathrm{a}$ & 0.31 & 0.35 & $0.39 \mathrm{~b}$ & $0.37 \mathrm{~b}$ \\
\hline & +0.19 & +4.9 & +0.88 & +5.92 & +4.36 & +10.3 & +5.78 & +7.00 & +0.01 & +0.00 & +0.00 & +0.00 \\
\hline \multirow{2}{*}{ W } & $80.1 \mathrm{~b}$ & 321 & $374 b$ & $775 b$ & $251 \mathrm{~b}$ & $894 b$ & $807 b$ & $1951 \mathrm{c}$ & 0.31 & 0.35 & $0.46 a$ & $0.39 \mathrm{a}$ \\
\hline & +1.22 & +8.41 & +3.38 & +4.33 & +3.48 & +10.17 & +2.00 & +8.45 & +0.01 & +0.00 & +0.00 & +0.00 \\
\hline \multirow{2}{*}{ LW100+ } & $81.6 \mathrm{ab}$ & 325 & $395 a$ & $801 \mathrm{ab}$ & $254 b$ & $911 \mathrm{ab}$ & $832 b$ & $1997 b$ & 0.32 & 0.35 & $0.47 \mathrm{a}$ & $0.40 \mathrm{a}$ \\
\hline & +0.64 & +1.76 & +10.8 & +12.7 & +7.21 & +21.4 & +2.64 & +24.6 & +0.01 & +0.00 & +0.01 & +0.00 \\
\hline \multirow{2}{*}{ LW150+ } & $85.1 \mathrm{a}$ & 324 & $379 \mathrm{ab}$ & 788ab & $262 b$ & $889 b$ & $812 b$ & $1964 b$ & 0.32 & 0.36 & $0.46 a$ & $0.39 \mathrm{a}$ \\
\hline & +1.30 & +3.21 & +2.84 & +7.42 & +3.28 & +12.6 & +3.7 & +7.44 & +0.01 & +0.00 & +0.00 & +0.00 \\
\hline Sig & $*$ & N.S & $*$ & $*$ & $*$ & $*$ & $*$ & $*$ & N.S & N.S & $*$ & $*$ \\
\hline
\end{tabular}

PIS = Protein Intake Starter, $P I G=$ Protein Intake Grower, $P I F=$ Protein Intake Finisher, PIT $=$ Protein Intake Total

$C P S=$ Protein Conversion Starter, $C P G=$ Protein Conversion Grower, $C P F=$ Protein Conversion Finisher

$C P T=$ Protein Conversion Total . 
Table (12). Effect of cereal type and enzyme supplementation on carcass traits of boiler chicks.

\begin{tabular}{|c|c|c|c|c|c|c|c|c|}
\hline $\begin{array}{l}\text { Pram. } \\
\text { Treat. }\end{array}$ & $\begin{array}{l}\text { Hot } \\
\text { carcass }\end{array}$ & liver & Heart & Gizzard & $\begin{array}{l}\text { Abdominal } \\
\text { Fat }\end{array}$ & Giblet & $\begin{array}{l}\text { Total } \\
\text { Edible } \\
\text { part }\end{array}$ & $\begin{array}{l}\text { Dressing } \\
\%\end{array}$ \\
\hline \multicolumn{9}{|l|}{ Corn } \\
\hline \multirow{2}{*}{$\mathrm{C}+$} & 71.60 & 2.30 & 0.44 & $1.66 \mathrm{a}$ & 2.37 & 4.39 & 76.00 & 90.99 \\
\hline & +0.79 & +0.14 & +0.03 & +0.05 & +0.14 & +0.18 & +0.89 & +0.27 \\
\hline \multirow{2}{*}{$\mathrm{C}$} & 71.38 & 2.20 & 0.41 & $1.42 \mathrm{~b}$ & 2.17 & 4.04 & 75.42 & 91.36 \\
\hline & +0.53 & +0.08 & +0.01 & +0.04 & +0.19 & +0.11 & +0.58 & +0.35 \\
\hline \multirow{2}{*}{$\begin{array}{l}\text { SIG } \\
\text { Wheat }\end{array}$} & N.S & N.S & N.S & $*$ & N.S & N.S & N.S & N.S \\
\hline & & & & & & & & \\
\hline \multirow{2}{*}{$\mathrm{W}+$} & $73.45 \mathrm{a}$ & 2.35 & 0.46 & $1.76 \mathrm{a}$ & 2.57 & 4.58 & $78.03 \mathrm{a}$ & 91.06 \\
\hline & +0.6 & +0.10 & +0.03 & +0.09 & +0.08 & +0.17 & +0.57 & +0.11 \\
\hline \multirow{2}{*}{ W } & $71.43 b$ & 2.27 & 0.45 & $1.54 \mathrm{~b}$ & 2.67 & 4.26 & $75.70 b$ & 91.31 \\
\hline & +0.44 & +0.07 & +0.01 & +0.04 & +0.17 & +0.07 & +0.44 & +0.39 \\
\hline SIG & $*$ & N.S & N.S & $*$ & N.S & N.S & $*$ & N.S \\
\hline \multicolumn{9}{|c|}{ Cereal Sources } \\
\hline \multirow{2}{*}{ C } & 71.38 & 2.20 & $0.41 \mathrm{~b}$ & 1.42 & 2.17 & 4.04 & 75.42 & 91.36 \\
\hline & +0.53 & +0.08 & +0.01 & +0.04 & +0.19 & +0.11 & +0.58 & +0.35 \\
\hline \multirow{2}{*}{ W } & $71.43 b$ & 2.27 & $0.45 \mathrm{a}$ & $1.54+$ & $267+017$ & $426+007$ & 75.70 & 91.31 \\
\hline & +0.44 & +0.07 & +0.01 & 0.04 & $2.67+0.17$ & $4.26+0.07$ & +0.44 & +0.39 \\
\hline SIG & N.S & N.S & $*$ & N.S & N.S & N.S & N.S & N.S \\
\hline
\end{tabular}

Table (13). Effect of low energy diets supplemented by enzymes cocktail on carcass characteristics of boiler chicks.

\begin{tabular}{lllllllll}
\hline $\begin{array}{l}\text { Pram. } \\
\text { Treat. }\end{array}$ & $\begin{array}{l}\text { Hot } \\
\text { carcass }\end{array}$ & liver & Heart & Gizzard & $\begin{array}{l}\text { Abdominal } \\
\text { Fat }\end{array}$ & Giblet & $\begin{array}{l}\text { Total } \\
\text { Edible } \\
\text { part }\end{array}$ & $\begin{array}{l}\text { Dressing } \\
\%\end{array}$ \\
\hline C & $71.38 \mathrm{c}$ & $2.21 \mathrm{bc}$ & $0.41 \mathrm{bc}$ & $1.42 \mathrm{~b}$ & 2.17 & $4.03 \mathrm{c}$ & $75.42 \mathrm{bc}$ & 91.36 \\
& +0.53 & +0.08 & +0.01 & +0.04 & +0.19 & +0.11 & +0.58 & +0.35 \\
LC100+ & $72.70 \mathrm{~b}$ & $2.41 \mathrm{ab}$ & $0.39 \mathrm{c}$ & $1.48 \mathrm{ab}$ & 2.24 & $4.28 \mathrm{ab}$ & $76.98 \mathrm{ab}$ & 92.52 \\
& +1.03 & +0.06 & +0.02 & +0.04 & +0.08 & +0.1 & +0.97 & +0.56 \\
LC150+ & $73.53 \mathrm{a}$ & $2.06 \mathrm{c}$ & $0.41 \mathrm{ab}$ & $1.52 \mathrm{ab}$ & 1.96 & $3.99 \mathrm{c}$ & $77.52 \mathrm{a}$ & 92.43 \\
& +0.81 & +0.06 & +.01 & +0.06 & +0.09 & +0.08 & +0.75 & +0.90 \\
$\mathrm{~W}$ & $71.43 \mathrm{c}$ & $2.27 \mathrm{ab}$ & $0.45 \mathrm{a}$ & $1.54 \mathrm{ab}$ & 2.67 & $4.26 \mathrm{ab}$ & $75.70 \mathrm{ab}$ & 91.31 \\
& +0.43 & +0.07 & +.02 & +0.04 & +0.18 & +0.07 & +0.44 & +0.39 \\
LW100+ & $72.08 \mathrm{~b}$ & $2.44 \mathrm{a}$ & $0.42 \mathrm{ab}$ & $1.62 \mathrm{a}$ & 2.52 & $4.48 \mathrm{a}$ & $76.56 \mathrm{ab}$ & 90.97 \\
& +0.35 & +0.06 & +.01 & +0.06 & +0.24 & +0.06 & +0.32 & +0.35 \\
LW150+ & $70.13 \mathrm{c}$ & $2.26 \mathrm{ab}$ & $0.44 \mathrm{ab}$ & $1.63 \mathrm{a}$ & 2.59 & $4.34 \mathrm{a}$ & $74.46 \mathrm{c}$ & 90.88 \\
$\mathrm{SIG}$ & +0.39 & +0.07 & +.01 & +0.04 & +0.19 & +0.09 & +0.36 & +0.68 \\
\hline
\end{tabular}


Table (14). Effect of cereal type and enzyme supplementation on some blood parameters (mg/dl).

\begin{tabular}{llllll}
\hline $\begin{array}{l}\text { Items } \\
\text { Treatments }\end{array}$ & Glucose & Total lipid & Total protein & Albumin & Globulin \\
\hline Corn & & & & & \\
C+ & $319 \mathrm{a}+9.25$ & $374+34.5$ & $3.95+0.17$ & $2.66+.24$ & $1.29+0.14$ \\
C & $289 \mathrm{~b}+8.03$ & $386+35.8$ & $4.21+0.09$ & $2.66+.24$ & $1.55+0.21$ \\
SIG & $*$ & N.S & N.S & N.S & N.S \\
Wheat & & & & \\
W+ & $260 \mathrm{a}+18.7$ & $386+35.8$ & $4.20+0.22$ & $2.83+0.22$ & 1.370 .20 \\
W & $210 \mathrm{~b}+3.02$ & $374+22.2$ & $3.86+0.11$ & $2.48+.24$ & $1.37+0.15$ \\
SIG & $* *$ & N.S & N.S & N.S & N.S \\
Cereal Sources & & & & & \\
C & $289 \mathrm{a}+.03$ & $386+35.8$ & $4.21 \mathrm{a}+0.09$ & $2.66+0.24$ & $1.55+.21$ \\
W & $210 \mathrm{~b}+3.08$ & $374+22.3$ & $3.86 \mathrm{~b}+0.11$ & $2.48+0.24$ & $1.37+.15$ \\
SIG & $*$ & N.S & N.S & N.S & N.S \\
\hline
\end{tabular}

Table (15). Effect of low energy diets supplemented by enzymes cocktail on some blood parameters (mg/dl).

\begin{tabular}{llllll}
\hline $\begin{array}{l}\text { Pram } \\
\text { Treatm. }\end{array}$ & Glucose & Total lipid & Total protein & Albumin & Globulin \\
\hline C & $289 \mathrm{ab}+8.03$ & $386+35.8$ & $4.21+0.09$ & $2.65+0.24$ & $1.55+0.21$ \\
LC100+ & $316 \mathrm{a}+3.30$ & $326+31.0$ & $4.03+0.11$ & $2.83+0.17$ & $1.19+0.15$ \\
LC150+ & $279 \mathrm{ab}+17.9$ & $362+26.4$ & $3.89+0.10$ & $2.66+0.31$ & $1.24+0.25$ \\
W & $210 \mathrm{c}+3.03$ & $374+22.2$ & $3.86+0.10$ & $2.48+0.24$ & $1.37+0.15$ \\
LW100+ & $271 \mathrm{ab}+21.9$ & $362+37.4$ & $3.85+0.24$ & $2.65+0.20$ & $1.19+0.14$ \\
LW150+ & $247 \mathrm{bc}+23.6$ & $386+35.8$ & $3.98+0.24$ & $2.66+0.20$ & $1.32+0.09$ \\
SIG & $* *$ & N.S & N.S & N.S & N.S \\
\hline
\end{tabular}

Table (16). Effect of main factors on European Production Efficiency Index (EPEI).

\begin{tabular}{lc}
\hline Items & EPEI \\
Treatments & $318 \mathrm{a} \pm 1.20$ \\
\hline C+ & $302 \mathrm{~b} \pm 1.45$ \\
C & $*$ \\
SIG & $284 \mathrm{a} \pm 0.88$ \\
W+ & $247 \mathrm{~b} \pm 0.88$ \\
W & $* *$ \\
SIG & $302 \mathrm{a} \pm 1.45$ \\
C & $247 \mathrm{~b} \pm 0.88$ \\
W & $*$ \\
SIG & \\
\hline
\end{tabular}

Table (17). Effect of low energy diets supplemented by enzymes Cocktail on European Production Efficiency Index.

\begin{tabular}{lc}
\hline Items & EPEI \\
Treatments & $302.3 \mathrm{a} \pm 1.45$ \\
\hline C & $300 \mathrm{a} \pm 7.55$ \\
LC100+ & $290 \mathrm{a} \pm 4.40$ \\
LC150+ & $247 \mathrm{~b} \pm 0.88$ \\
W & $253 \mathrm{~b} \pm 5.69$ \\
LW100+ & $247 \mathrm{bc} \pm 0.88$ \\
LW150+ & $*$ \\
SIG & \\
\hline
\end{tabular}


تأثير نوع الحبوب وإضافة الآنزيمات المحلله للمواد الكربوهيدراتيه الغير نثويه على أداء دجاج اللحم وكفاعة الاستفاده من عناصر الغذاء وأو الآي

طارق محمد يونس*، فتحى عدلى محمد*، فؤاد محمد عطيه*، محمد أحمد سيد** و أحمد السيد العراقي شمس

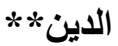
* * قسم الاتتاج الحيوانى - كلية الزراعه بالقاهزه - جامعة الازهر -مدينة نصر - القاهره - جمهورية مصر العربيه. *** قسم تغنية الدواجن_معهل بحوث الاتتاج الحيوانسيمركز البحوث الزراعية - جمهورية مصر العربيه.

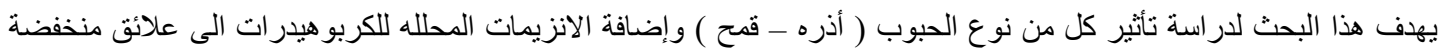

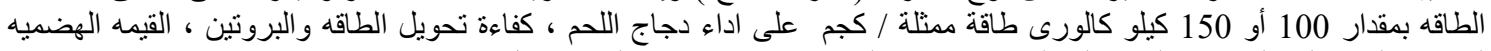

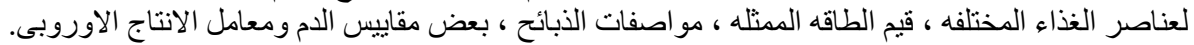

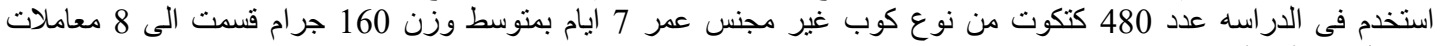
وتحنوى كل معامله على 3 مكررات.

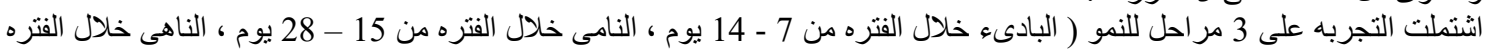

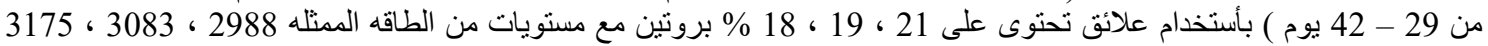
كيلو كالورى / كجم من العلائق خلال مر احل البادىه ، النامى و الناهى على التو الثى .فى كل مرحله من مر احل النمو تم تغذية كل مجمو عهد

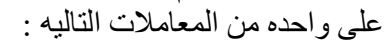

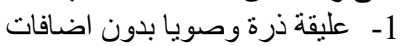

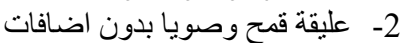

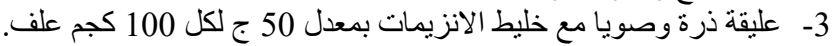

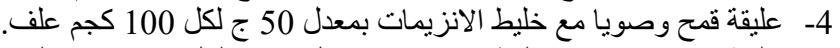

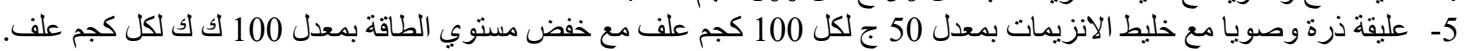

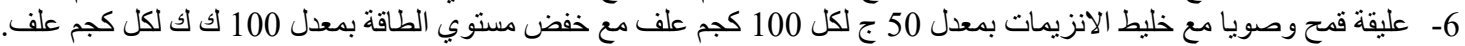

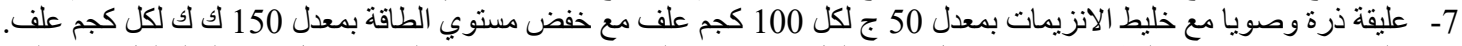

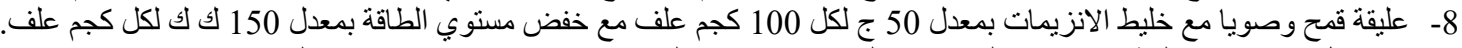

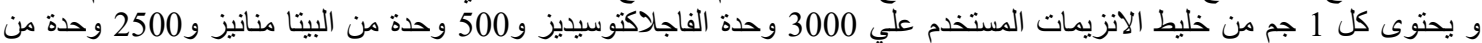
الزيلانيز و1500 وحدة بيتا جلو كانيز و و1000 وحدة سيلليوز . ويمكن تلخيص النتائج المتحصل عليها كالتالي. • تفوقت الطيور المغذاه علي علائق تحتوى على الذرة والصويا في كل من معدل زيادة وزن الجسم وكمية الغذاء المستهلك و ومعامل

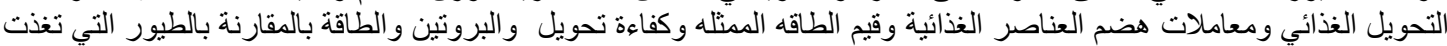

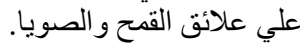

• اضافة خليط الانزيمات الى كل من علائق الذرة و الصويا وعلائق القمح و الصويا حسن قيم كل المقاييس المختبره الدذكوره سابقا.

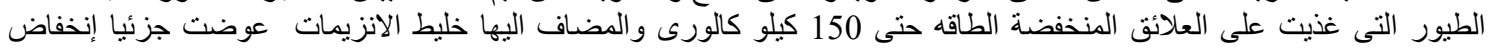

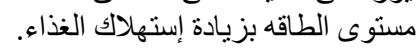

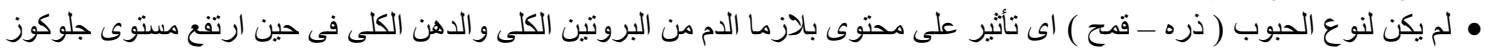

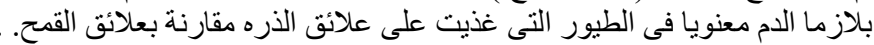

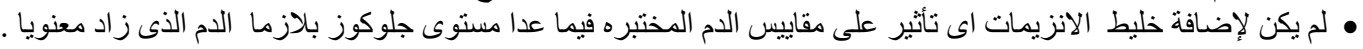

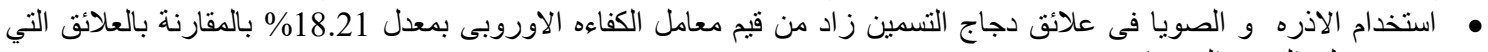

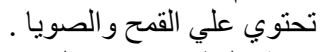

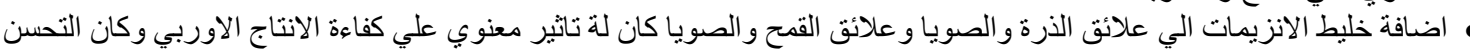

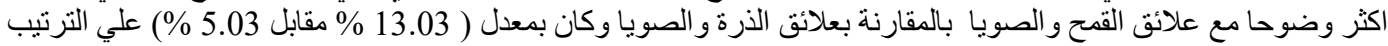

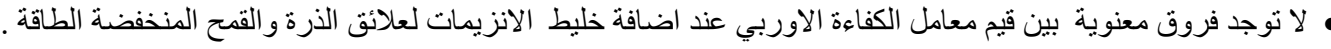

